DOI: https://doi.org/10.31933/jimt.v2i5 Received: 28 April 2021, Revised: 25 Mei 2021, Publish: 8 Juli 2021

JIMT
JUINASTI
JERALAL ILMU MANAJEMEN
TERAPAN

\title{
DETERMINASI KINERJA KEUANGAN PERUSAHAAN : ANALISIS LIKUIDITAS, LEVERAGE DAN UKURAN PERUSAHAAN (LITERATURE REVIEW MANAJEMEN KEUANGAN)
}

\author{
Dewi Purwanti ${ }^{1}$ \\ ${ }^{1}$ Mahasiswa Program Magister Manajemen, Universitas Mercu Buana, \\ dpurwanti284@gmail.com
}

\section{Corresponding author: Dewi Purwanti ${ }^{1}$}

\begin{abstract}
Abstrak: Riset terdahulu atau riset yang relevan sangat penting dalam suatu riset atau artikel ilmiah. Riset terdahulu atau riset yang relevan berfungsi untuk memperkuat teori dan fenomena hubungan atau pengaruh antar variabel. Artikel ini mereview Determinasi Kinerja Keuangan Perusahaan : Analisis Likuiditas, Leverage, dan Ukuran Perusahaan Suatu Studi Literatur Manajemen Keuangan. Hasil dari library research ini adalah bahwa: 1) Likuiditas berpengaruh terhadap kinerja keuangan perusahaan; 2) Leverage berpengaruh terhadap kinerja keuangan perusahaan; 3) Ukuran perusahaan tidak berpengaruh terhadap kinerja keuangan perusahaan.
\end{abstract}

Kata Kunci: Likuiditas, Leverage, Ukuran Perusahaan, Kinerja Keuangan.

\section{PENDAHULUAN}

\section{Latar Belakang Masalah.}

Setiap mahasiswa baik Strata 1, Strata 2 dan Strata 3, di wajibkan untuk melakukan riset dalam bentuk skripsi, tesis dan disertasi. Begitu juga bagi dosen, peneliti dan tenaga fungsional lainya aktif melakukan riset dan menyusun artikel ilmiah untuk di publikasi pada jurnal-jurnal ilmiah.

Berdasarkan pengalaman empirik banyak mahasiswa, dosen muda dan juga peneliti lainnya, memiliki kesulitan untuk mencari artikel pendukung dalam riset sebagai penelitian terdahulu atau sebagai penelitian yang relevan. Artikel sebagai peneliti yang relevan di perlukan untuk memperkuat teori yang di teliti, untuk melihat hubungan antar variabel dan membangun hipotesis sangat diperlukan pada bagian pembahasan hasil penelitian.

Artikel ini membahas Pengaruh Likuiditas, Leverage dan Ukuran Perusahaan terhadap Kinerja Keuangan Perusahaan (Suatu Studi Literatur Manajemen Keuangan). Tentu tidak semua faktor yang mempengaruhi Kinerja Keuangan Perusahaan pada artikel ini, ini hanya sebagian kecil saja yang akan di kaji dan di review. 
Secara rinci tujuan dari penulisan "Literature Review Paper" ini adalah mengetahui pengaruh atau hubungan antara variabel exogen Likuiditas, Leverage dan Ukuran Perusahaan terhadap variabel endogen Kinerja Keuangan Perusahaan.

1) Pengaruh atau hubungan likuiditas terhadap kinerja keuangan perusahaan.

2) Pengaruh atau hubungan leverage terhadap kinerja keuangan perusahaan.

3) Pengaruh atau hubungan ukuran perusahaan terhadap kinerja keuangan perusahaan.

\section{KAJIAN TEORI}

\section{Kinerja Keuangan Perusahaan}

Salah satu hal yang dapat dilihat dalam menilai kualitas dari suatu perusahaan adalah kinerja keuangan perusahaan. Kinerja keuangan perusahaan (financial performance) yang bagus akan memberikan penilaian kualitas yang bagus pada perusahaan, sebaliknya jika kinerja keuangan perusahaan buruk maka akan memberikan penilaian yang buruk juga terhadap kualitas perusahaan. Kinerja keuangan adalah suatu analisis yang dilakukan untuk melihat sejauh mana suatu perusahaan telah melaksanakan dengan menggunakan aturan-aturan pelaksanaan keuangan secara baik dan benar.(Fahmi, 2013:239).

Kinerja keuangan perusahaan dapat tercermin dan dapat dilihat dari laporan keuangan yang dimiliki perusahaan. Informasi keuangan pada laporan keuangan terdiri dari neraca (Balance Sheet), laporan laba/rugi (Profit and Loss), Laporan Cashflow dan hal-hal lain yang turut mendukung sebagai penguat penilaian kinerja keuangan. Berdasarkan Ikatan Akuntan Indonesia (IAI) dalam PSAK No. 1 tahun 2015 (2015:1) menjelaskan bahwa laporan keuangan adalah suatu penyajian yang terstruktur dari posisi keuangan dan kinerja keuangan suatu entitas.

Manajemen perusahaan akan membuat laporan keuangan sebagai bentuk pertanggung jawaban atas kinerjanya dalam satu periode yang akan dipertanggung jawabkan kepada pihak internal perusahaan maupun eksternal perusahaan yang berkepentingan terhadap kinerja keuangan perusahaan. Laporan keuangan dapat dianalisis melalui rasio-rasio keuangan guna melihat kinerja keuangan perusahaan. Kasmir (2018:104) menjelaskan bahwa rasio keuangan merupakan suatu kegiatan membandingkan angka-angka yang ada di dalam laporan keuangan dengan cara membagi satu angka dengan angka lainnya. Rasio keuangan merupakan sebuah alat untuk manajemen dalam menganalisa laporan keuangan serta menilai kinerja perusahaan.

Kinerja keuangan perusahaan biasa dikaitkan dengan laba yang dihasilkan oleh perusahaan atau pengukurannya melalui profitabilitas. Sartono dalam Fatmawati (2017:19) menjelaskan bahwa profitabilitas adalah kemampuan dari suatu perusahaan dalam memperoleh laba dalam hubungannya dengan penjualan, total aset maupun modal sendiri. Indikator yang dapat digunakan dalam mengukur profitabilitas perusahaan dengan menggunakan rasio Return on Equity (ROE). Dimana rumus Return on Equity (ROE) sebagai berikut :

\section{Return on Equity $($ ROE) = Laba Bersih Setelah Pajak} Ekuitas

Profitabilitas perusahaan sudah banyak di teliti oleh peneliti sebelumnya di antaranya adalah (Erick et al., 2016), (Lubis et al., 2017), dan (Masyitah E \& Kahar H, 2018).

\section{Rasio Likuiditas}

Likuiditas merupakan kemampuan perusahaan untuk memenuhi kewajiban finansialnya yang harus dipenuhi tepat waktu (Munawir dan Satriana, 2017:18). Rasio likuiditas bertujuan untuk mengukur seberapa besar kemampuan perusahaan dalam membayarkan kewajiban jangka pendeknya. Salah satu indikator rasio yang digunakan untuk mengukur likuiidtas perusahaan yaitu dengan menghitung Current ratio (CR). Rumus dari Current Assets sebagai berikut : 


\section{Current Assets $=$ Aset Lancar \\ Utang Lancar}

Semakin rendahnya nilai dari $C R$, maka akan mengindikasikan ketidakmampuan perusahaan dalam memenuhi kewajiban jangka pendeknya, sehingga hal ini dapat mempengaruhi tingkat profitabilitas perusahaan, dimana perusahaan yang tidak mampu memenuhi kewajibannya akan dikenai beban tambahan atas kewajibannya. Apabila mengukur tingkat likuiditas dengan menggunakan $C R$ sebagai alat pengukurnya, maka tingkat likuiditas atau $C R$ suatu perusahaan dapat dipertinggi dengan cara menggunakan utang lancar tertentu, diusahakan untuk menambah aktiva lancar dan aktiva lancar tertentu diusahakan untuk mengurangi jumlah utang lancar (Syahrial, 2013).

Rasio likuiditas ini sudah banyak di teliti oleh peneliti sebelumnya di antaranya adalah (PA \& Marbun, 2016), (Masyitah E \& Kahar H, 2018), (Sunardi \& Febrianti, 2020).

\section{Rasio Leverage}

Rasio leverage bertujuan untuk mengukur seberapa jauh perusahaan menggunakan hutang (Kasmir, 2012). Leverage menunjukkan penggunaan hutang yang berperan dalam upaya peningkatan kinerja keuangan karena dengan leverage perusahaan-perusahaan yang memperoleh sumber dana dengan berhutang dapat mengetahui sejauh mana pengaruh pinjaman yang diambil perusahaan terhadap peningkatan kinerja keuangan perusahaan. Perhitungan Leverage dapat menggunakan rasio Debt to equity ratio (DER). Debt to equity ratio (DER) adalah rasio yang mengukur perbandingan antara total hutang dengan total modal. DER membandingkan sumber ekuitas dari hutang dengan ekuitas sendiri. Rumus DER sebagai berikut :

$$
\text { Debt to Equity Ratio }(\text { DER })=\frac{\text { Total utang }}{\text { Ekuitas }}
$$

Rasio leverage sudah banyak di teliti oleh peneliti sebelumnya di antaranya adalah (Ifada \& Inayah, 2017), (Azis \& Hartono, 2017), dan (Erawati \& Wahyuni, 2019).

\section{Ukuran Perusahaan}

Ukuran perusahaan merupakan suatu skala dimana dapat diklasifikasikan besar kecilnya perusahaan diukur dengan total aset, jumlah penjualan, nilai saham dan sebagainya. (Putu Ayu dan Gerianta, 2018). Berdasarkan Badan Standarisasi Nasional, ukuran perusahaan dibagi menjadi tiga jenis, yaitu:

a. Perusahaan besar adalah perusahaan yang memiliki kekayaan bersih lebih besar dari Rp. 10 Milyar termasuk tanah dan bangunan. Memiliki penjualan lebih dari Rp. 50 Milyar/tahun.

b. Perusahaan menengah adalah perusahaan yang memiliki kekayaan bersih Rp. 1-10 Milyar termasuk tanah dan bangunan. Memiliki hasil penjualan lebih besar dari Rp. 1 Milyar dan kurang dari Rp. 50 Milyar.

c. Perusahaan kecil adalah perusahaan yang memiliki kekayaan bersih paling banyak Rp. 200 Juta tidak termasuk tanah dan bangunan dan memiliki hasil penjualan minimal Rp. 1 Milyar/tahun.

Ukuran perusahaan sudah banyak diteliti oleh peneliti sebelumnya diantaranya (Lutfi \& Sunardi, 2019), (Cahyana \& Suhendah, 2020), (Jufrizen \& Fatin, 2020).

\section{METODE PENULISAN}

Metode penulisan artikel ilmiah ini adalah dengan metode kuantitatif dan studi literature atau Library Research. Mengkaji Buku-buku literature sesuai dengan teori yang di bahas 
khusunya di lingkup Manajemen Keuangan. Disamping itu menganalisis artikel-artikel ilmiah yang bereputasi dan juga artikel ilmiah dari jurnal yang belum bereputasi. Semua artikel ilmiah yang di citasi bersumber dari Mendeley dan Scholar Google.

Dalam penelitian kualitatif, kajian pustaka harus digunakan secara konsisten dengan asumsi-asumsi metodologis. Artinya harus digunakan secara induktif sehingga tidak mengarahkan pertanyaan-pertanyaan yang diajukan oleh peneliti. Salah satu alasan utama untuk melakukan penelitian kualitatif yaitu bahwa penelitian tersebut bersifat eksploratif, (Ali \& Limakrisna, 2013).

Selanjutnya dibahas secara mendalam pada bagian yang berjudul" Pustaka Terkait" (Related Literature) atau Kajian pustaka( "Review of Literature"), sebagai dasar perumusan hipotesis dan selanjutnya akan menjadi dasar untuk melakukan perbandingan dengan hasil atau temuan-temuan yang terungkap dalam penelitian, (Ali \& Limakrisna, 2013).

\section{PEMBAHASAN}

\section{Pengaruh Likuiditas terhadap Kinerja Keuangan Perusahaan}

Likuiditas merupakan tolak ukur kemampuan perusahaan dalam memenuhi kewajiban jangka pendeknya. Semakin tinggi tingkat likuiditas perusahaan maka kinerja akan semakin baik. Penelitian dari (Fajrin \& Laily, 2016), (PA \& Marbun, 2016), (Sunardi \& Febrianti, 2020) menyatakan bahwa likuiditas memiliki pengaruh positif Kinerja Perusahaan.

\section{Pengaruh Leverage terhadap Kinerja Keuangan Perusahaan}

Leverage dapat diukur melalui rasio leverage dan memiliki tujuan untuk mengetahui seberapa jauh perusahaan menggunakan hutang (Kasmir, 2012). Leverage atau biasa disebut dengan solvabilitas dapat menggunakan indikator Debt to Equity Ratio (DER). Penelitian dari (Ifada \& Inayah, 2017), (Azis \& Hartono, 2017), (Erawati \& Wahyuni, 2019) menyatakan bahwa leverage memiliki pengaruh negative terhadap kinerja keuangan perusahaan.

\section{Pengaruh Ukuran Perusahaan terhadap Kinerja Keuangan Perusahaan}

Ukuran perusahaan merupakan beasr atau kecilnya suatu perusahaan. Ukuran perusahaan dapat diukur dari aset yang dimiliknya, ukuran perusahaan juga merupakan suatu ukuran yang dapat mempengaruhi meningkatnya kinerja perusahaan. Penelitian dari (Pertiwi, 2018), (Christine et al., 2019), (Jufrizen \& Fatin, 2020) menyatakan bahwa ukuran perusahaan tidak berpengauh signifikan terhadap kinerja perusahaan.

\section{Conceptual Framework}

Berdasarkan rumusan masalah penulisan artikel ini dan kajian studi literature review baik dari buku dan artikel yang relevan, maka di perolah rerangka artikel ini seperti di bawah ini. 


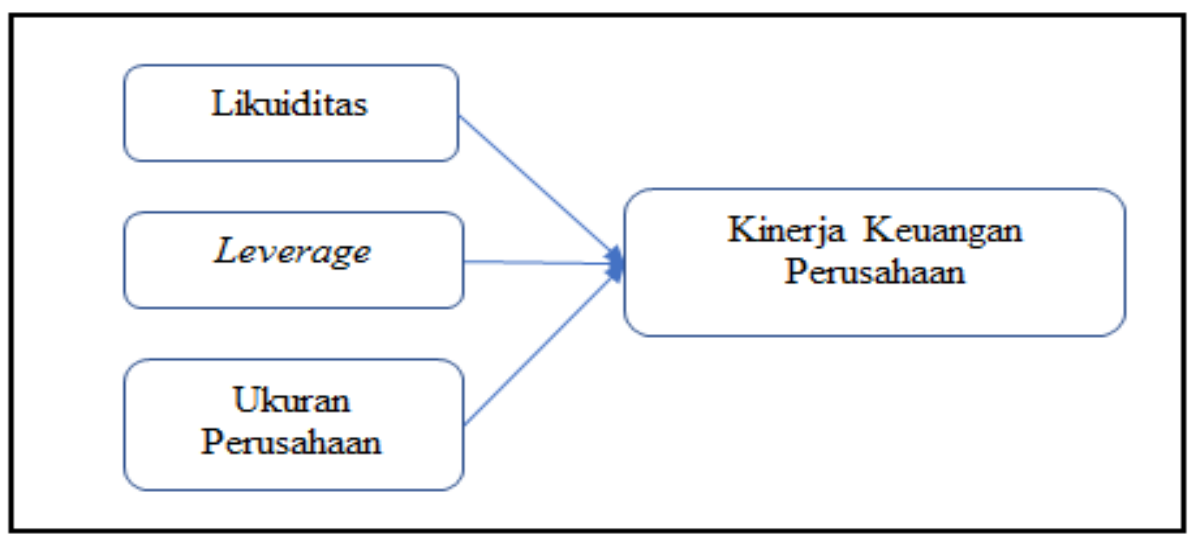

\section{Gambar 1: Kerangka Berfikir}

Likuiditas, leverage dan ukuran perusahaan memilii hubungan dan berpengaruh terhadap kinerja keuangan perusahaan baik secara langsung maupun tidak langsung.

Selain dari variabel likuiditas, leverage dan ukuran perusahaan yang mempengaruhi kinerja keuangan perusahaan masih banyak variabel lain yang mempengaruhinya, di antaranya adalah variabel:

1) Cashflow: (Syamsudin et al., 2019), (Rambe, 2020), (Catherine \& Nariman, 2020).

2) Corporate Governance : (Eksandy, 2018), (Hendratni et al., 2018), (Syamsudin et al., 2019).

3) Sales Growth : (Andelline, 2018), (Lutfi \& Sunardi, 2019), (Cahyana \& Suhendah, 2020).

\section{KESIMPULAN DAN SARAN \\ Kesimpulan}

Berdasarkan rumusan artikel, hasil dan pembahasan, maka dapat di di rumuskan hipotesis untuk riset selanjutnya:

1. Likuiditas berpengaruh terhadap kinerja keuangan perusahaan

2. Leverage berpengaruh terhadap kinerja keuangan perusahaan.

3. Ukuran Perusahaan tidak berpengaruh terhadap kinerja keuangan perusahaan.

\section{Saran}

Berdasarkan kesimpulan di atas, maka saran pada artikel ini adalah bahwa masih banyak faktor lain yang mempengaruhi kinerja keuangan perusahaan, selain dari likuiditas, leverage dan ukuran perusahaan pada semua tipe dan level organisasi atau perusahaan, oleh karena itu masih di perlukan kajian yang lebih lanjut untuk mencari faktor-faktor lain apa saja yang dapat memepengaruhi kinerja keuangan perusahaan selain yang di teliti pada artikel ini.

\section{DAFTAR PUSTAKA}

Andelline, S. (2018). Pengaruh Working Cpital Turnover, Total Asset Turnover, Asset Growth, dan Sales Growth Terhadap Kinerja Keuangan Perusahaan Consumer Goods yang Terdaftar di Bursa Efek Indonesia Selama Tahun 2013-2016. Jurnal Manajemen Bisnis Dan Kewirausahaan, 2(2), 57-65. 
Azis, A., \& Hartono, U. (2017). Pengaruh Good Corporate Governance, Struktur Modal, Dan Leverage Terhadap Kinerja Keuangan Perusahaan Pada Sektor Pertambangan Yang Terdaftar Di Bursa Efek Indonesia Tahun 2011-2015. Jurnal Lmu Manajemen, 5(3), 113.

Cahyana, A. M. K., \& Suhendah, R. (2020). Pengaruh Leverage, Firm Size , Firm Age Dan Sales Growth Terhadap Kinerja Keuangan. Multoparadigma Akuntansi Tarumanegara, 2, 1791-1798.

Catherine, \& Nariman, A. (2020). Pengaruh Intellectual Capital, Free Cash Flow, Dan Struktur Modal Terhadap Kinerja Keuangan. Jurnal Multiparadigma Akuntansi Tarumanegaraarumanegara, 2, 1186-1195. http://journal.untar.ac.id/index.php/jpa/article/view/9545

Christine, D., Wijaya, J., Chandra, K., Pratiwi, M., Lubis, M. S., \& Nasution, I. A. (2019). Pengaruh Profitabilitas, Leverage, Total Arus Kas dan Ukuran Perusahaan terhadap Financial Distress pada Perusahaan Property dan Real Estate yang Terdapat di Bursa Efek Indonesia Tahun 2014-2017. Jesya (Jurnal Ekonomi \& Ekonomi Syariah), 2(2), 340-350. https://doi.org/10.36778/jesya.v2i2.102

Eksandy, A. (2018). Pengaruh Good Corporate Governance Terhadap Kinerja Keuangan Pada Perbankan Syari'Ah Indonesia. Jurnal Akuntansi : Kajian Ilmiah Akuntansi (JAK), 5(1), 1. https://doi.org/10.30656/jak.v5i1.498

Erawati, T., \& Wahyuni, F. (2019). PENGARUH CORPORATE GOVERNANCE, UKURAN PERUSAHAAN, DAN LEVERAGE TERHADAP KINERJA KEUANGAN PERUSAHAAN DI BURSA EFEK INDONESIA (Studi Kasus Perusahaan Manufaktur Yang Terdaftar di Bursa Efek Indonesia Periode 2013-2017). Jurnal Akuntansi Pajak Dewantara, 1(2), 129-137. https://doi.org/10.24964/japd.v1i1.895

Erick, M. C. J., Miranda, G., Sandra, D., Argueta, E., Wacher, N. H., Silva, M., Valdez, L., Cruz, M., Gómez-Díaz, R. A., Casas-saavedra, L. P., De Orientación, R., Salud México, S. de, Virtual, D., Instituto Mexicano del Seguro Social, Mediavilla, J., Fernández, M., Nocito, A., Moreno, A., Barrera, F., ... Faizi, M. F. (2016). Title. Revista CENIC. Ciencias Biológicas, 152(3), 28. file:///Users/andreataquez/Downloads/guia-plan-demejora-

institucional.pdf\%0Ahttp://salud.tabasco.gob.mx/content/revista\%0Ahttp://www.revista alad.com/pdfs/Guias_ALAD_11_Nov_2013.pdf\%0Ahttp://dx.doi.org/10.15446/revfacm ed.v66n3.60060.\%0Ahttp://www.cenetec.

Fajrin, P. H., \& Laily, N. (2016). Analisis Profitabilitas dan Likuiditas Terhadap Kinerja Keuangan PT. Indofood Sukses Makmur, Tbk. Jurnal Ilmu Dan Riset Manajemen, 5(6), 01-17.

Hendratni, T. W., Nawasiah, N., \& Indriati, T. (2018). Analisis Pengaruh Corporate Governance Terhadap Kinerja Keuangan Sektor Perbankan Yang Terdaftar Di Bei Tahun 2012-2016. Jurnal Riset Manajemen Dan Bisnis (JRMB) Fakultas Ekonomi UNIAT, 3(1), 37-52. https://doi.org/10.36226/jrmb.v3i1.83

Ifada, L. M., \& Inayah, N. (2017). Analisis Pengaruh Tingkat Leverage Terhadap Kinerja Perusahaan (Studi Pada Perusahaan Food and Beverage Yang Terdaftar di BEI Tahun 2011-2013). Fokus Ekonomi, 12(1), 19-36. http://ejournal.stiepena.ac.id/index.php/fe/article/view/160

Jufrizen, J., \& Fatin, I. N. Al. (2020). Pengaruh Debt To Equity Ratio, Return On Equity, Return On Assets Dan Ukuran Perusahaan Terhadap Nilai Perusahaan Pada Perusahaan 
Farmasi. Jurnal Humaniora: Jurnal Ilmu Sosial, Ekonomi Dan Hukum, 4(1), 183-195.

Lubis, I. L., Sinaga, B. M., \& Sasongko, H. (2017). Pengaruh Profitabilitas, Sruktur Modal, Dan Likuiditas Terhadap Nilai Perusahaan. Jurnal Aplikasi Bisnis Dan Manajemen, 3(3), 458-465. https://doi.org/10.17358/jabm.3.3.458

Lutfi, A. M., \& Sunardi, N. (2019). PENGARUH CURRENT RATIO (CR), RETURN ON EQUITY (ROE), DAN SALES GROWTH TERHADAP HARGA SAHAM YANG BERDAMPAK PADA KINERJA KEUANGAN PERUSAHAAN (Pada Perusahaan Manufaktur Sektor Makanan dan Minuman Yang terdaftar di Bursa Efek Indonesia). Jurnal SEKURITAS (Saham, Ekonomi, Keuangan Dan Investasi), 2(3), 83. https://doi.org/10.32493/skt.v2i3.2793

Masyitah E \& Kahar H. (2018). Analisis Kinerja Keuangan Menggunakan Rasio Likuiditas Dan Profitabilitas. Jurnal Akuntansi Dan Keuangan Kontemporer, 14(1), 46.

PA, M., \& Marbun, D. (2016). Pengaruh Current Ratio Dan Debt To Equity Ratio Terhadap Return On Assets. Widyakala Journal, 3, 23. https://doi.org/10.36262/widyakala.v3i0.21

Pertiwi, D. A. (2018). Pengaruh Rasio Keuangan, Growth, Ukuran Perusahaan, dan Inflasi Terhadap Financial Distress di Sektor Pertambangan Yang Terdaftar DI Bursa Efek Indonesia (BEI) Periode 2012-2016. Jurnal Ilmu Manajemen (JIM), 6(3), 359-366. https://jurnalmahasiswa.unesa.ac.id/index.php/jim/article/view/24314

Rambe, B. H. (2020). Analisis Ukuran Perusahaan, Free Cash Flow(Fcf) Dan Kebijakan Hutang Terhadap Kinerja Keuangan Pada Perusahaan Manufaktur Yang Terdaftar Di Bursa Efek Indonesia. Ecobisma (Jurnal Ekonomi, Bisnis Dan Manajemen), 7(1), 54-64. https://doi.org/10.36987/ecobi.v7i1.1530

Sunardi, N., \& Febrianti, F. (2020). Likuiditas dan Kebijakan Hutang Pengaruhnya terhadap Kinerja Perusahaan dan Dampaknya Terhadap Nilai Perusahaan pada Industri Sektor Telekomunikasi di Indonesia. JIMF (Jurnal Ilmiah Manajemen Forkamma), 3(3), 269282. https://doi.org/10.32493/frkm.v3i3.6206

Syamsudin, R., Afifudin, \& Junaidi. (2019). Pengaruh Good Corporate Governance, Free Cash Flow Dan Leverage Terhadap Kinerja Keuangan Perusahaan Lq45 Di Bei. E-Jra, 08(5), $147-162$. 